\title{
Terminalia catappa Extract Enhances Erythropoiesis in Adult Balb C Mice
}

\author{
I. A. Aimola (Corresponding author) \\ Biochemistry Unit, National Research Institute for Chemical Technology \\ Zaria, Nigeria \\ E-mail: idowuaimola@gmail.com
}

H. M. Inuwa

Biochemistry Department, Ahmadu Bello University

Zaria, Nigeria

A. I. Mamman

Hematology Department, Ahmadu Bello University Teaching Hospital

Zaria, Nigeria

N. Habila \& A. S. Agbaji

Biochemistry Unit, National Research Institute for Chemical Technology

Zaria, Nigeria

D. Omoniwa

Veterinary Physiology and Pharmacology

Ahmadu Bello University, Zaria, Nigeria

Received: April 30, 2011 Accepted: May 13, $2011 \quad$ Published: December 31, 2011

doi:10.5539/jmbr.v1n1p40

URL: http://dx.doi.org/10.5539/jmbr.v1n1p40

\begin{abstract}
Anemia and low haemoglobin levels are complications frequently associated with Sickle cell disease and $\beta$-thalasssemia. Chemotherapy of these haemoglobinopathies involves the use of drugs which increase haemoglobin levels. The use of Terminalia catappa traditionally for the treatment of SCD dates back. Herein we evaluated the potential of Terminalia catappa to induce erythropoiesis in adult Balb $C$ mice. The methanolic extract of Terminalia catappa induced production of haemoglobin higher than that of an untreated control after 6 days. The PCV of treated and untreated mice was also assessed and found to be relatively higher in Terminalia catappa treated mice comparable to mice administered with folic acid.
\end{abstract}

Keywords: Terminalia catappa, Erythropoiesis, Sickle cell disease, Balb C mice

\section{Introduction}

Sickle cell anaemia is a genetic disorder which results from a mutation in the $17^{\text {th }}$ nucleotide of the $\beta$-globin gene that leads to the substitution of glutamic acid by Valine as the $6^{\text {th }}$ amino acid of the $\beta$-chain of haemoglobin (Bindon, 2004). The disease is characterized with symptoms of varying degree, including haemolytic anaemia as a result of polymerization of the red cells in situations of low oxygen tension. The nti-i-chemical properties of haemoglobin-S form the basis for sickle cell related morbidity. Intra-erythrocytic hypoxia causes haemoglobin polymerization with associated change in red cell shape-sickling. The sickle red cells are rigid with an increased tendency to stick to endothelial surface. Erythrocyte adhesion to endothelium is the basis for vaso-occlusion 
manifested as bone pain, strokes, chest syndrome and priapism. Since the Haemoglobin-S containing erythrocytes are more prone to haemolysis, hence sickle cell disease patients are frequently anaemic (Aliyu et al.,2007; Bownas, 2002; Bindon, 2004).

Sickle cell anaemia is a lifelong medical disorder of public health significance in most parts of the world (Weatherall 2010; Chowning 2000).

The use of herbs for the treatment of ailments is as old as man. Several herbs have been used to treat sickle cell disease traditionally (Elujoba et al., 2005).

Terminalia catappa (almond) one plant commonly used to treat sickle cell disease in Nigeria, has been shown to inhibit osmotically induced haemolysis. (Mgbemene et al., 1999). The plant which is also commonly called umbrella tree in northern Nigeria because of the shade the tree provides belongs to the family Combretaceae, and is known to originate from subtropical and tropical zones of India and pacific oceans (Thomson and Evans 2006). Almond plants have various traditional medicinal uses; the leaves, and fruit are use for treatment of pains and headache in Sri Lanka, dressing of rheumatic joints in Indonesia and India; the bark is used as a diuretic and cardiotonic, the leaves are also used for treatment of headache. In Nigeria, leaves macerated in palm oil used for nti-inflam; stems and bark used for sexual dysfunction. Seeds have been used for sexual dysfunction (http://www.stuartxchange.com/Talisay.html). It is also used to treat eye problems in Samoa and to stop bleeding during teeth extraction in Mexico (http://www.fishforums.net/index.php?/topic/41676-indian-almond-leaf/). The ethanol extract of the leaf show potential in the treatment of sickle cell disease (http://www.fishforums.net/index.php?/topic/41676-indian-almond-leaf/). Studies have shown that leave extracts of Terminalia catappa have potential to prevent metastasis (Chu et al., 2007), have antioxidant, hepatoprotective, antimicrobial, antiparasitic and antiinflamatory properties among others (Kinoshita et al., 2007; Babayi et al., 2004; Fan et al., 2004).

Inspite of several studies on the medicinal properties Terminalia catappa (Chu et al., 2007; Kinoshita et al., 2007; Babayi et al., 2004; Fan et al., 2004), Its ability to stimulate red blood cells (RBC) production in vivo has not been reported even though it is used as a long term efficacious traditional therapy for SCD. The dearth of scientific validation of plant based sickle cell therapies as reported by Okpuzor et al (2008) is the thrust of investigating the efficacy of Terminalia catappa methanolic extract on erythropoiesis in Adult Balb C mice.

\section{Materials and Methods}

T. catappa leaves were obtained fresh in the early hours of the morning and identified at the Ahmadu Bello University herbarium. The fresh leaves were air dried at room temperature within the laboratory.

\subsection{Plant extraction}

The dried leaves of $T$. catappa leaves were pulverized using a mortar and pestle. $10 \mathrm{~g}$ of the pulverized leaves was then exhaustively extracted using methanol at boiling point. The extract was then allowed to cool to room temperature and then cryo-concentrated.

\subsection{Animal experiments}

The concentrated extract was reconstituted in PBS pH 7.2 and administered intraperitoneally to Balb C mice at a dosage of $80 \mathrm{mg} / \mathrm{kg}$ bodyweight. $\mathrm{LD}_{50}$ of plant extract was previously determined (results not shown) in this lab. Here, the lethal dose of the extract was carried out as described by Lorke 1983 to ascertain the number of surviving animals at $50 \%$. The animal grouping consisted four mice per group and the groupings were; a positive control (administered with folic acid 80mg/ml), negative control (only PBS administered) and test group (administered with $80 \mathrm{mg} / \mathrm{kg} \mathrm{T}$. catappa extract). The administration was allowed to run for 7 days with administration being carried out daily. At the end of the $7^{\text {th }}$ day mice were sacrificed and blood collected in EDTA. The haemoglobin, PCV and WBC levels were determined.

\subsection{Haemoglobin assay}

Haemoglobin was assayed as previously described Khalid et al., (2003) with slight modifications. Briefly; cells were washed twice with phosphate-buffered saline (PBS), resuspended in $0.5 \mathrm{~mL}$ distilled water, and lysed under hypotonic conditions for 10 minutes. The cell lysate was centrifuged at $10000 \mathrm{rpm}$ in a microfuge for 15 minutes at $37{ }^{\circ} \mathrm{C} .200 \mu \mathrm{l}$ of the supernatant was used for the assay. The assay mixture was prepared in duplicate by adding the reagents in the following order: $100 \mu \mathrm{L}$ supernatant, $900 \mu \mathrm{L}$ distilled water, $100 \mu \mathrm{L}$ freshly prepared benzidine- $\mathrm{HCl}(10 \mathrm{mg} / \mathrm{mL}), 40 \mu \mathrm{L}$ of $30 \% \mathrm{H}_{2} \mathrm{O}_{2}$. The contents were mixed well and after exactly 90 seconds the absorbance at $604 \mathrm{~nm}$ was measured in a Shimadzu UV-Vis spectrophotometer. Hemoglobin concentration was 
determined by comparing this absorbance value to a standard curve prepared using pure human hemoglobin solutions.

\subsection{UV spectral scan determination}

The concentrated extract was reconstituted in methanol and diluted three folds. $3 \mathrm{ml}$ of the dilute extract was scanned in a Shimadzu UV-visible spectrophotometer. Wavelength range of scan was between $200-800 \mathrm{~nm}$.

\subsection{Phytochemical analysis}

This was carried out according to the method of Trease and Evans (1989) as previously described by Harborne (1973) and modified by Edeoga (2005).

\subsection{Statistical analysis}

The means of the different groups were compared using the Student t-test.

\section{Results}

\subsection{Terminalia catappa improves intracellular hemoglobin}

Erythropoiesis was studied by monitoring the level of intracellular haemoglobin in both untreated and Terminalia catappa treated Balb $C$ mice and compared with that of the control. The level of intracellular haemoglobin was significantly higher in Terminalia catappa treated mice $(\mathrm{P}<0.05)$ as compared to the untreated control Balb $\mathrm{C}$ mice (Figure 1). There was no significant difference $(\mathrm{P}<0.05)$ between the intracellular hemoglobin levels of both the Terminalia catappa treated and Folic acid treated groups.

\subsection{Terminalia catappa induces production of total formed elements of blood}

The ability of Terminalia catappa to improve the overall formed elements of the blood was also assessed by determining the effect of Terminalia catappa extract on the PCV of adult Balb C mice 7 days post treatment of the mice using T. catappa extract.

Terminalia catappa induced a significantly higher percentage increase $(\mathrm{P}<0.05)$ in PCV (Table 1$)$ of mice 7 days post treatment comparable to folic acid as opposed to the untreated control. The relative increase in PCV in mice treated with Terminalia catappa is shown in Figure 2.

\subsection{Phytochemical profile of Terminalia catappa}

The phytochemical content of Terminalia catappa extract revealed the presence of alkaloids and anthraquinones (Table 2).

\section{$3.4 U V$-visible absorbance spectra of methanolic extract of Terminalia catappa}

The spectra was carried out at every 0.5 interval in a $1 \mathrm{~cm}$ quartz cuvette, covering a scan range of $200-800 \mathrm{~nm}$. The spectra revealed the presence of several prominent peaks at $260,334,418,435,468,615$ and $664 \mathrm{~nm}$ as shown in Figure 4.

\section{Discussion}

The management of sickle cell disease involves the use of chemical agents that enhance erythropoesis to ameliorate the symptoms of anaemia. Terminalia catappa has been used for many years in northern Nigeria to manage sickle cell aneamia . herein we investigated the effect of the extract of Terminalia catappa on Balb C mice intracellular haemoglobin and PCV level. The plant extract was therapeutic at a dose of $80 \mathrm{mg} / \mathrm{kg}$ body weight of adult Balb $\mathrm{C}$ mice. The plant extract induced intracellular haemoglobin levels significantly above the untreated control and comparable to that of the folic acid, this could be one of the medicinal benefits of the plant which has enabled its use over time locally.

The precise mechanism by which the extract induces erythropoeisis can not be said at this point, but the findings is consistent with previous studies by Mgbemene et al., 1999 which demonstrated that $T$. catappa was able to inhibit osmotically induced haemolysis. Thus it is possible that the extract posses some haemotopoetic protective effect.

In order to ascertain the haematopeitic inductive potential of T. catappa we assessed its effect on the PCV of Balb $\mathrm{C}$ mice before and after treatment of the mice. The extract showed $16.67 \%$ induction of the PCV level of the mice close to Folic acid which revealed a 25\% increase in PCV of the mice on the other hand the untreated control showed an almost steady PCV level during the 7 day experimental period. This could be important in the management of sickle cell anemia since anaemia as revealed by a much lowered PCV levels in sickle cell anaemia patients is one of the major ways in which the disease is expressed (Buchanan et al., 2004). Although further studies is needed to understand the mechanism behind these induction. 
We also monitored the effect of the extract on the weight of the mice to see if the extract enhances feeding in mice this revealed no effect of the extract on the animals in feeding behavior of the extract, as there was a slight decrease in the bodyweight of the mice after the 7 days experimental period as shown in Figure 3.

The phytochemical content revealed the presence of alkaloids and anthraquinones which could be responsible for the observed effects of the plant extract, the UV-Visible absorbace spectra also revealed distinct peaks which could represent characteristic compounds which would require further studies for complete characterization. These plant components could by acting in synergy to elicit their haematopoetic and erythropoietic effects but this would also require further characterization.

In summary, methanolic extract of Terminalia catappa revealed an erythropoeitic potential in adult Balb C mice. The extract induced intracellular haemoglobin levels higher than an untreated control and comparable to that of a standard erythropoeitic drug Folic acid the extract also showed haematopoetic potential being able to increase the PCV of the mice significantly above the control 7 days post treatment of the mice with the extract. The phytochemical and UV-Visible spectra reveal the presence of alkaloids and anthraquinones. More studies is required to ascertain the precise mechanism in which the methnolic extract of Terminalia catappa elicits its erythropoietic effect in Balb C mice and also the active principles involved which can enhance plant based drug development.

\section{Reference}

Aliyu Z. Y., Gordeuk V., Sachdev V., et al. (2008). Prevalence and risk factors for pulmonary artery systolic hypertension among sickle cell disease patients in Nigeria. American Journal of Hematology, 83, 485-490. http://dx.doi.org/10.1002/ajh.21162

Babayi H., Kolo I., Okogun J. I. \& Ijah U. J. J. (2004). The antimicrobial activities of methanolic extracts of Eucalyptus camaldulensis and Terminalia catappa against some pathogenic microorganisms. Biokemistri, 16(2), 106-111.

Bindon, J. (2004). Natural Selection and Adaptation: Sickle Cell. [Online] Available: http://www.as.ua.edu/ant/bindon/ant475/Sicklecell/Sicklecell.pdf

Bownas, J. (2002). Genetic Profile: Sickle Cell Anaemia. National Institute of Health Publication, No. 96-4057.

Brugnara C. (2000). Red Cell Dehydration In Pathophysiology And Treatment Of Sickle Cell Disease, Departments of Pathology and Laboratory Medicine, Harvard Medical School, Boston, Massachusetts. [Online] Available: http://www.med.harvard.edu/

Buchanan G. R., DeBaun M. R., Quinn C. T., \& Steinberg M. H. (2004). Sickle Cell Disease, Hematology, 35(1), 1243-1249.

Chowning T. J. (2000). A Case Study Approach to Teaching High School. Genetics, [Online] Available: http://genetics-education-partnership.mbt.washington.edu/Download/file.html

Chu S. C, Yang S. F, Liu S. J, Kuo W. H, Chang Y. Z \& Hsieh Y. S. (2007). In vitro and in vivo antimetastatic effects of Terminalia catappa L. leaves on lung cancer cells. Food and chemical toxicology, 45(7), 1194-1201. http://dx.doi.org/10.1016/j.fct.2006.12.028

Edeoga H. O., Okwu D. E. \& Mbaebie B. O. (2005). Phytochemical Constituents of some Nigerian Medicinal Plants. African Journal of Biotechnology, 4(7), 685-688.

Elujoba A. A, Odeleye O. M \& Ogunyemi C. M. (2005). Traditional Medical Development for medical and dental primary Health care Delivery System in Africa. African Journal of Traditional, Complementry Alternative Medicine.2(1), 46-61.

Fan, Y. M., Xu, L. Z., Gao, J., et al. (2004). Phytochemical and nti-inflammatory studies on Terminalia catappa. Fitoterapia, (75), 253-260. http://dx.doi.org/10.1016/j.fitote.2003.11.007

Harborne J. B. (1973). Phytochemical Methods. Chapman and Hall Ltd. Pp. 49-188.

Khalid Hafid-Medheb, Yvette Augery-Bourget, Marie-Nathalie Minatchy, et al. (2003). Bcl-XL is required for heme synthesis during the chemical induction of erythroid differentiation of murine erythroleukemia cells independently of its antiapoptotic function. Blood, 101(7). 2575-2583. http://dx.doi.org/10.1182/blood-2002-02-0478

Kinoshita S, Inoue Y, Nakama S, Ichiba T \& Aniya Y. (2007). Antioxidant and hepatoprotective actions of medicinal herb, Terminalia catappa L from Okinawa Island and its tannin corilagin. Phytomedicine, 14, 755-62. http://dx.doi.org/10.1016/j.phymed.2006.12.012 
Lorke D. (1983). A new approach to practical acute toxicity testing. Achives. Of Toxicology. 54, 275-287. http://dx.doi.org/10.1007/BF01234480

Mgbemene C. N. \& Ohiri F. C. (1999). Anti-sickling potential of Terminalia catappa leaf extract. Pharmaceutical biology. 37(2). 152-154. http://dx.doi.org/10.1076/phbi.37.2.152.6090

Okpuzor J., Adebesin O., Henrietta O. H. \& Amadi I. (2008). The Potential of medicinal plants in sickle cell disease control: A review. International Journal of Biomedical and Health Sciences, 4(2), 47-55.

Thomson \& Evans. (2006). Species Profiles for Pacific Island Agroforestry. [Online] Available: http://www.agroforestry.net/tti/T.catappa-tropical-almond.pdf

Trease G. E. \& Evans W. C. (1989). Pharmacognosy. $11^{\text {th }}$ edition. Brailliar Tridel Can. Macmillian publishers.

Weatherall D. J. (2010). The inherited diseases of hemoglobin are an emerging global health burden. Blood, 115(22), 4331-4336. http://dx.doi.org/10.1182/blood-2010-01-251348

Table 1. Percentage Induction of PCV of adult Balb C mice after 7 days treatment with methanolic extract of Terminalia catappa Folic acid was used as control drug and compared with an untreated control. PCV was determined using the capillary technique and measured using a haematocrit reader

\begin{tabular}{|l|l|}
\hline Folic acid & $25 \% \pm 2.5$ \\
\hline Untreated control & $2.33 \% \pm 2.0$ \\
\hline Terminalia catappa & $16.67 \% \pm 1.6$ \\
\hline
\end{tabular}

Table 2. phytochemical content of methanolic extract of Terminalia catappa extract

\begin{tabular}{|l|l|l|}
\hline & Phytochemical & Status \\
\hline 1 & Saponins & Absent \\
\hline 2 & Alkaloids & Present \\
\hline 3 & Flavonoids & Absent \\
\hline 4 & Anthraquinones & Present \\
\hline 5 & Glycosides & Absent \\
\hline
\end{tabular}




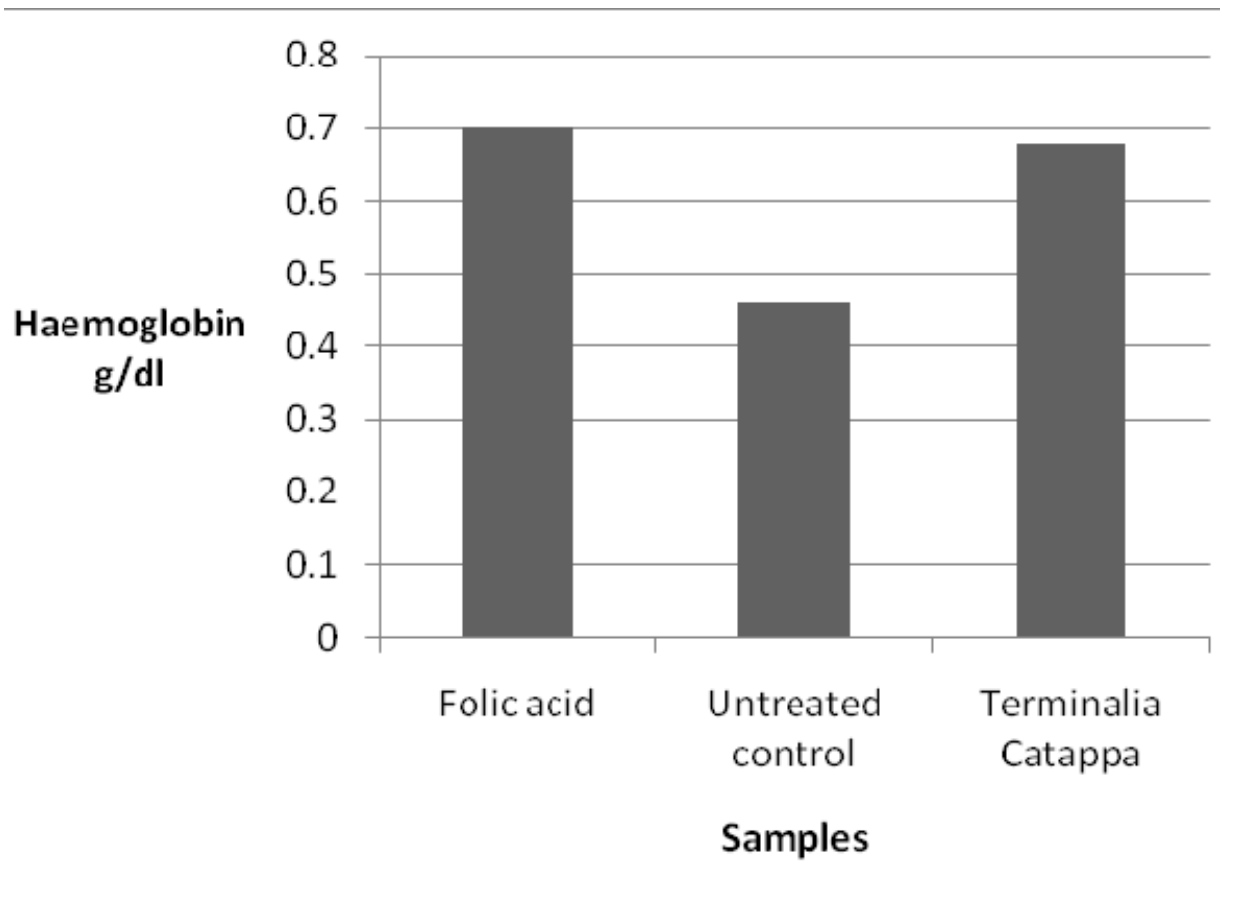

Figure 1. Terminalia catappa induced haemoglobin levels higher than the untreated control and comparable to Folic acid. Intracellular haemoglobin levels were measured after 7 days of treatment with extract by the benzidine spectrophotometric assay using human haemoglobin as standard

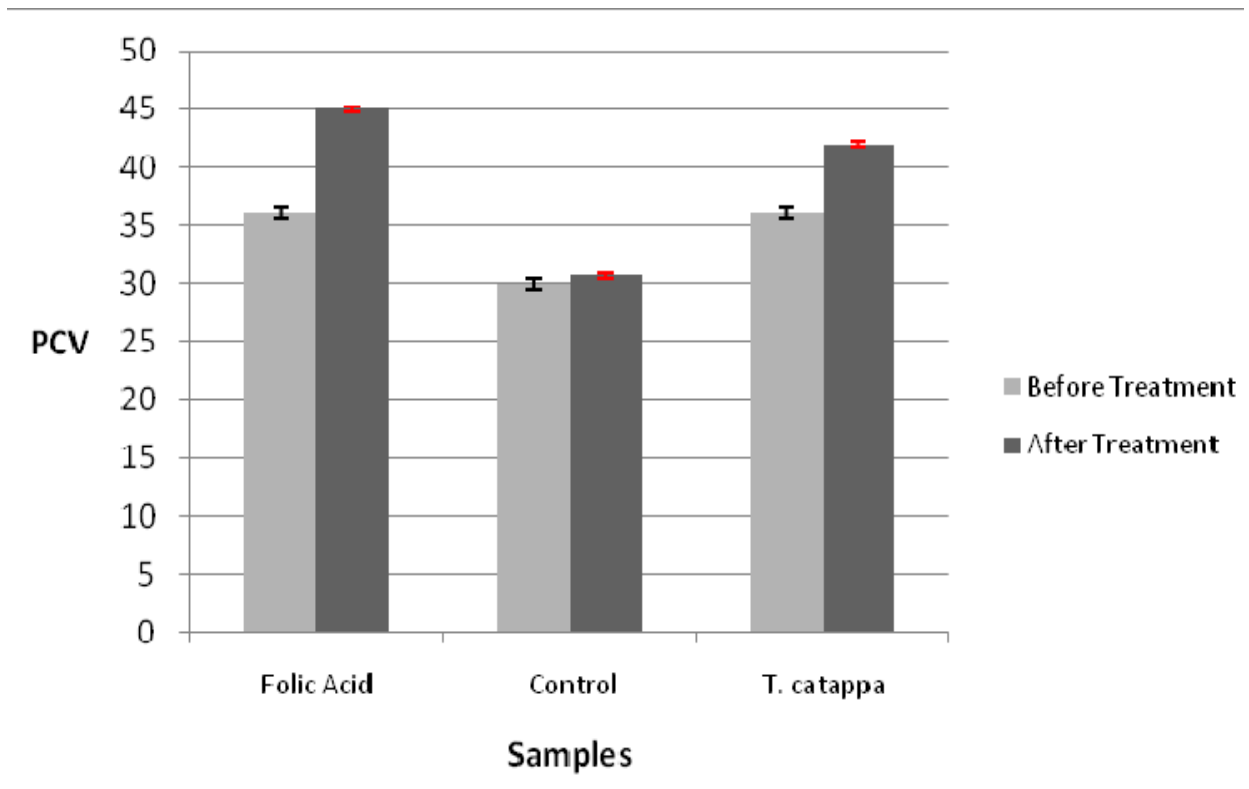

Figure 2. Terminalia catappa improves PCV levels in adult Balb C mice Terminalia catappa extract was administered at a dosage of $80 \mathrm{mg} / \mathrm{kg}$. mice were sacrificed by humane decapitation, and their blood collected in EDTA and PCV was determined by benzidine spectrophotometric assay method as previously described by Khalid et al. (2003) $\mathrm{P}<0.05$ for both folic acid and T. catappa 


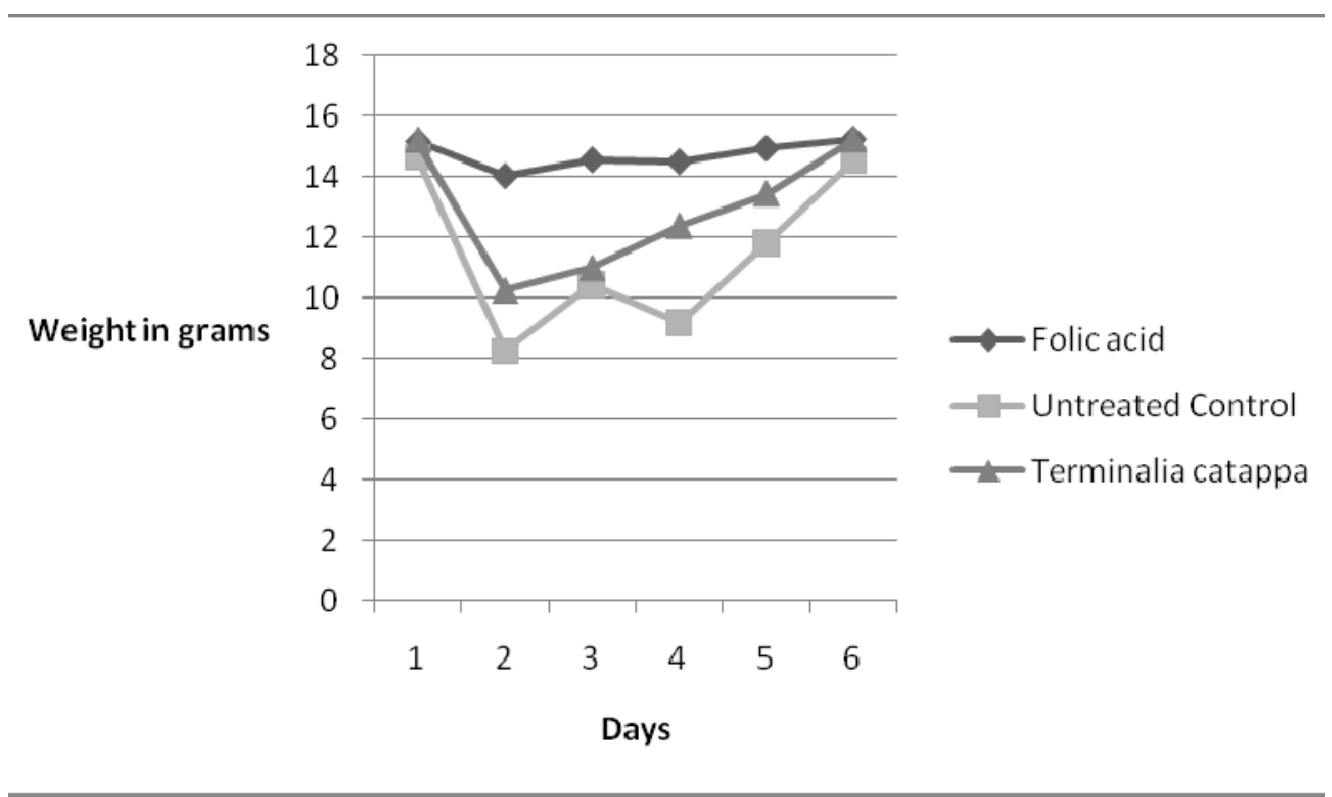

Figure 3. Effect of Terminalia catappa extract on the mean weight of adult Balb $C$ mice: weight was measured using a Mettler top loading balance at every 24 hours interval for 7 days

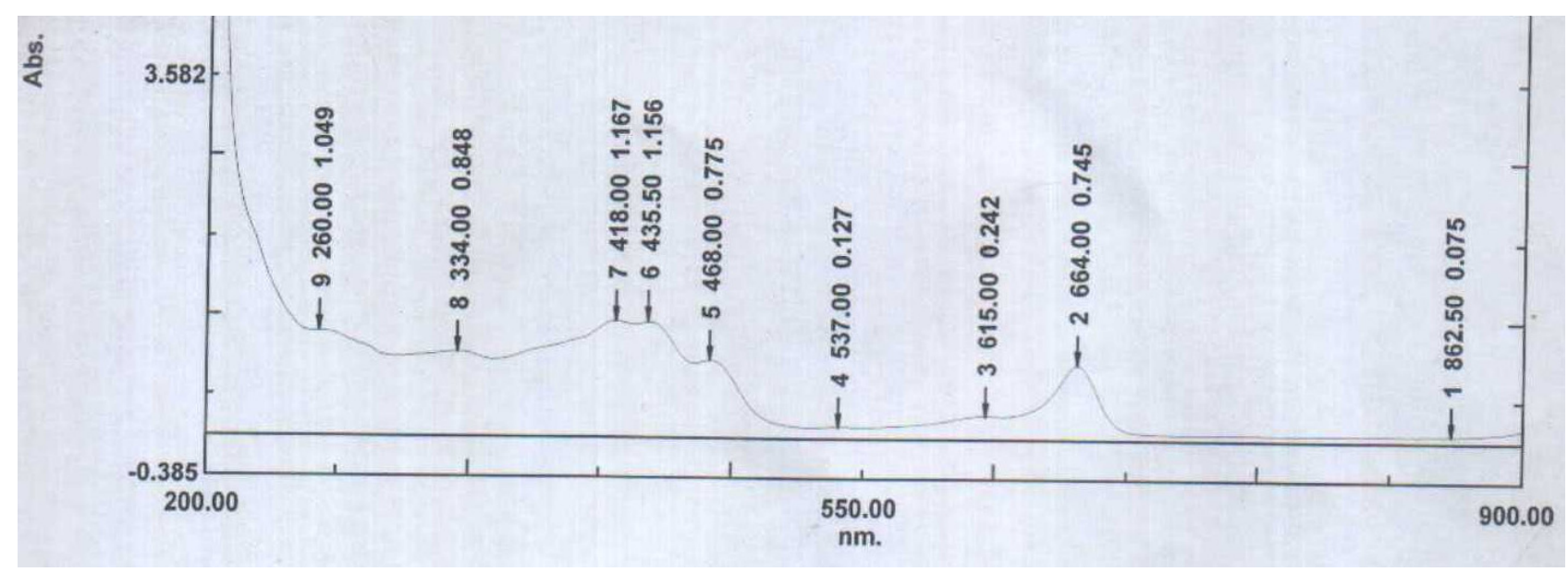

Figure 4. UV-Visible absorbance spectra of Terminalia catappa methanolic extract in PBS buffer pH 7.2 path length of $1 \mathrm{~cm}$ in a quartz cuvette 